\title{
Investigation on binary copper-based catalysts used in the ethanol steam reforming process
}

\author{
Łukasz Hamryszak ${ }^{1}$ (D) - Maria Madej-Lachowska² • Maria Kulawska' • \\ Małgorzata Ruggiero-Mikołajczyk ${ }^{3} \cdot K_{\text {Katarzyna Samson }}^{3} \cdot$ Michał Śliwa $^{3}$
}

Received: 5 April 2020 / Accepted: 9 July 2020 / Published online: 15 July 2020

(c) The Author(s) 2020

\begin{abstract}
The use of copper-based binary catalysts, $\mathrm{Cu} / \mathrm{Zr}$ oxides and $\mathrm{Cu} / \mathrm{Al}$ oxides, has been examined to produce hydrogen from ethanol in the ethanol steam reforming process. The examined catalysts were compared with non-noble bicomponent catalysts consisting of oxides of nickel and cobalt: $\mathrm{Ni} / \mathrm{Zr} \mathrm{Co} / \mathrm{Zr}, \mathrm{Ni} / \mathrm{Al}$ and $\mathrm{Co} / \mathrm{Al}$, prepared and tested in the identical way. Catalytic tests were carried out in the fixed-bed reactor in the temperature range $433-873 \mathrm{~K}$ for initial molar ratio of ethanol to water equal to 1:3. Ethanol conversion approached near 100\%. Catalysts were characterized by XRD, TPR. Cu/Zr oxides. The catalyst showed very good selectivity. It is significant that carbon monoxide appeared only above $600 \mathrm{~K}$ and its selectivity has not exceeded $3 \%$ in the higher temperature range. No methane has been detected. Hydrogen yield was relatively stable in the temperature range from 513 to $873 \mathrm{~K}$. Similarly, in the presence of $\mathrm{Cu} / \mathrm{Al}$ oxides neither $\mathrm{CO}$ nor $\mathrm{CH}_{4}$ were found in the products. The correlation between activity of examined catalysts and textural properties was not found.
\end{abstract}

Keywords Copper catalysts · Ethanol steam reforming · Hydrogen fuel cells · Hydrogen production · Non-noble metal catalysts

Łukasz Hamryszak

lukasz.hamryszak@interia.pl

1 Institute of Chemical Engineering, Polish Academy of Sciences, 5 Bałtycka Street, 44-100 Gliwice, Poland

2 Opole University of Technology, 31 Sosnkowskiego Street, 45-272 Opole, Poland

3 Jerzy Haber Institute of Catalysis and Surface Chemistry, Polish Academy of Sciences, 8 Niezapominajek Street, 30-239 Kraków, Poland 


\section{Introduction}

The increase in environmental pollution and new restrictions and regulations require new clean technologies of high energy efficiency, so the search for alternative sources of green energy. Nowadays there is no doubt that hydrogen is the most important carrier of clean energy [1]. Until today, it was produced in industry from gasification of coal and other fossil materials, in steam reforming of hydrocarbons (mainly methane) and oxygenates (mainly methanol) [2,3] and from electrolysis of water [4]. In last two decades ethanol steam reforming is of great interest because ethanol is safe and easy in storage and distribution. There are many sources of cheap ethanol like biomass and all substrates with starch content [5].

The main reaction of hydrogen production process from ethanol is strong endothermic [1]:

$$
\mathrm{C}_{2} \mathrm{H}_{5} \mathrm{OH}+3 \mathrm{H}_{2} \mathrm{O} \longleftrightarrow 2 \mathrm{CO}_{2}+6 \mathrm{H}_{2} \quad \Delta \mathrm{H}_{298}=+174 \mathrm{~kJ} / \mathrm{mol}
$$

Many side reactions occur in the ethanol steam reforming process forming undesired products as carbon monoxide, methane, acetic acid, acetaldehyde, ethene and others [6].

$$
\begin{aligned}
\mathrm{CH}_{3} \mathrm{CH}_{2} \mathrm{OH} & \longleftrightarrow \mathrm{CH}_{3} \mathrm{CHO}+\mathrm{H}_{2} \\
\mathrm{CH}_{3} \mathrm{CHO} & \longleftrightarrow \mathrm{CH}_{4}+\mathrm{CO} \\
\mathrm{CH}_{4}+\mathrm{H}_{2} \mathrm{O} & \longleftrightarrow \mathrm{CO}+3 \mathrm{H}_{2} \\
\mathrm{CH}_{3} \mathrm{CH}_{2} \mathrm{OH} & \longleftrightarrow \mathrm{C}_{2} \mathrm{H}_{4}+\mathrm{H}_{2} \mathrm{O} \\
\mathrm{C}_{2} \mathrm{H}_{4} & \longleftrightarrow 2 \mathrm{C}+2 \mathrm{H}_{2} \\
\mathrm{C}_{2} \mathrm{H}_{4}+2 \mathrm{H}_{2} \mathrm{O} & \longleftrightarrow 2 \mathrm{CO}+4 \mathrm{H}_{2}
\end{aligned}
$$

It is known that even a little improvement in hydrogen selectivity and lowering of concentration of carbon monoxide in the product is very important because of poisoning effect of this in fuel cells. $\mathrm{CO}$ is a strong poison for PEFC anode catalysts, the system cannot accept more than $100 \mathrm{ppm}$ for efficient operation [5]. The methane has no negative effect on the anode, it can be used to provide heat for the endothermic reforming process [7]. As is evident, this is a process with a very complex mechanism, and therefore requires active and selective catalysts operating under severe conditions. At the same time it must be resistant to carbon deposition on the catalyst surface (coking) [8].

Up to now the noble metal (rhodium, platinum, ruthenium or iridium) catalysts have been applied in this process with good results [9-12]. Due to the high cost of precious metals, numerous efforts are undertaken to develop cheaper catalysts with comparable properties. 
The properties of catalysts depend mainly on their composition, especially on active metal content and support type, but also on all parameters of preparation. Most of the studies concern on nickel [5, 13-22] and cobalt [7, 8, 15, 16, 18-20, 23-28] based catalysts. In the literature available studies on nickel catalysts, the nickel content varies from 5 to 20 mass\% deposited on various supports [5, 22]. These catalysts are active in the ethanol steam reforming in the temperature range 573-923 K [1], with an optimal nickel content of about 10 mass\% [14, 16, 17]. Extensive research has been conducted on a number of different supports, of which oxides of Ti [16], Si Mg [13], La [15] and Zn [17] deserve attention. The studies on cobalt-based catalysts with a content of cobalt from 2 to 18 mass\% [7, 8, 15, 16, 18-20, 23-28] show increase in their activity with an increase of its content in the temperature range from 623 to $773 \mathrm{~K}[1,27]$. Oxides of $\mathrm{Zn}, \mathrm{Ce}, \mathrm{Sm}, \mathrm{La}[23]$ and Al [24] are listed as optimal supports for these catalysts.

An important problem concerning ethanol steam reforming process is catalyst deactivation caused by coking. Increase in acidity of active centres of the support gives decrease in activity because of increasing tendency to formation of carbon deposits (coking) [5] which main source is the dehydrogenation of ethanol followed by decomposition of ethene [6]. According to Padilla et al. [20] lanthanum addition causes gasification of deposited coke. The elimination of coking can be also realized by using of stoichiometric excess of water to ethanol from 2 to 18 [5].

There are not many works concerning catalysts based on copper. According to Rossetti et al. [16], those deposited on $\mathrm{TiO}_{2}$ show high resistance to coking. However, they exhibit poor ability to break the $\mathrm{C}-\mathrm{C}$ bonds, therefore acetaldehyde and ethylene predominate in the products; it indicates that the main source of hydrogen is the reaction of their dehydrogenation. Bergamaschi et al. [21] found the high catalyst activity of $\mathrm{Ni} / \mathrm{Cu}=8 / 3$ mass $\%$ complex supported on $\mathrm{ZrO}_{2}$. Vizcaíno et al. [6] found that in $\mathrm{Cu} / \mathrm{Ni}$ catalyst supported on $\mathrm{SiO}_{2}$ nickel is the phase responsible for hydrogen production while copper-for decrease both in $\mathrm{CO}$ formation and coke deposition.

There are great differences in reported works concerning active metal content and the tested parameters, especially in terms of steam excess. For this reason, it is very difficult to select the optimal catalyst composition on the base on literature data.

The aim of this work is to study the applicability of $\mathrm{Cu} / \mathrm{Zr}$ oxides and $\mathrm{Cu} / \mathrm{Al}$ oxides binary catalysts to produce hydrogen from ethanol. The activities of the tested $\mathrm{Cu} / \mathrm{Zr}$ oxides and $\mathrm{Cu} / \mathrm{Al}$ oxides catalysts were compared to those of nickel $(\mathrm{Ni} / \mathrm{Zr}$ and $\mathrm{Ni} / \mathrm{Al})$ and cobalt $(\mathrm{Co} / \mathrm{Zr}$ and $\mathrm{Co} / \mathrm{Al})$ oxides catalysts prepared by the same method and tested in the identical conditions.

\section{Experimental}

\section{Materials}

For the synthesis of catalysts: $\mathrm{Ni}\left(\mathrm{NO}_{3}\right)_{2} \cdot 6 \mathrm{H}_{2} \mathrm{O}, \mathrm{Co}\left(\mathrm{NO}_{3}\right)_{2} \cdot 6 \mathrm{H}_{2} \mathrm{O}, \mathrm{Cu}\left(\mathrm{NO}_{3}\right)_{2} \cdot 3 \mathrm{H}_{2} \mathrm{O}$, $\mathrm{ZrO}\left(\mathrm{NO}_{3}\right)_{2} \cdot \mathrm{H}_{2} \mathrm{O}$, purchased from Sigma-Aldrich Poland; citric acid monohydrate purchased from Stanlab Sp.j. Poland; 65 mass\% nitric acid, purchased from 
Avantor Performance Materials Poland; all of AR grade. To determine activity: ethanol Merck KGaA, gradient grade for liquid chromatography.

\section{Catalysts synthesis}

All catalysts have been prepared according to the method described by Courty et al. [29]. The method of complex formation of metals by citric acid and thermal decomposing the citrate complexes proved the best in our laboratory. The mixture is perfectly mixed because of branched structure of citrates. The use of citrate complexes gave excellent homogeneity and fully repeatable properties of the prepared catalyst [30], while the conventional method of co-precipitation did not provide such results, although the latter is usually used, as is known from the literature. The formed catalysts were calcinated in a muffle at temperature $623 \mathrm{~K}$. In all obtained catalysts the ratio of metal $(\mathrm{Ni}, \mathrm{Co}, \mathrm{Cu})$ oxide to alumina or zirconia, respectively, was the same, equal to $63.8 / 36.2$ (mass\%/mass $\%$ ).

\section{Catalysts characterization}

Phase analysis based on X-ray powder diffraction (XRD) measurements was performed on a X'PERT PRO MDP diffractometer with detector X'CELERATOR, working in Bragg-Brentano geometry. The XRD measurements (at $40 \mathrm{kV}$ and $30 \mathrm{~mA}$ ) were performed in the $2 \mathrm{~h}$ range from $5^{\circ}$ to $90^{\circ}$ with the interpolated step size $0.02^{\circ}$. The crystallite sizes were calculated from Scherrer method. XRD phase analysis was performed using reference standards from the International Centre for Diffraction Data (ICDD) PDF-4 database.

The specific surface area $\left(\mathrm{S}_{\mathrm{BET}}\right)$ and porosity of catalysts were determined with the Multi-Point BET Plot analysis method using an Autosorb-1 Quantachrome apparatus, with nitrogen as an adsorbate at $77 \mathrm{~K}$. Prior to the measurements, the samples were preheated and degassed under vacuum at $373 \mathrm{~K}$ for $18 \mathrm{~h}$. The micropore area was obtained by $\mathrm{V}$-t plot method $\mathrm{t}$-micropore analysis while pore size distribution was calculated with the BJH method.

$\mathrm{H}_{2}$-TPR (temperature-programmed reduction of $\mathrm{H}_{2}$ ) measurements were performed in Chembet-3000 (Quantachrome) u-shape quartz flow reactor (diameter ca. $5 \mathrm{~mm}$ ) at temperature range $300-1050 \mathrm{~K}$ with temperature ramp of $10 \mathrm{~K} / \mathrm{min}$ and a flow rate of $5 \% \mathrm{H}_{2}$ in Ar. Before the TPR analysis, all samples were kept in a stream of helium at $373 \mathrm{~K}$ for $1.5 \mathrm{~h}$ to remove physically adsorbed water.

Size of crystallites of tested catalysts are presented in Table 1. Catalyst composition and textural properties are presented in Table 2.

\section{Catalytic tests}

A continuous fixed-bed reactor of $8 \mathrm{~cm}^{3}$ volume, made of stainless steel, was used in the catalytic experiments. The bed consisted of $2 \mathrm{~g}$ of the catalyst of grain size of $0.8-1.0 \mathrm{~mm}$. The catalyst was reduced in a stream of diluted hydrogen $\left(7 \% \mathrm{H}_{2}\right.$ in $\left.\mathrm{N}_{2}\right)$ at $723 \mathrm{~K}$ under atmospheric pressure for $4 \mathrm{~h}$ and activated in the mixture of the reactants 
Table 1 Sizes of crystallites of tested catalysts

\begin{tabular}{lllllll}
\hline Catalyst & \multicolumn{7}{l}{ Size of crystallites $(\mathrm{nm})$} \\
\cline { 2 - 7 } & $\mathrm{Ni}(111)$ & $\mathrm{Co}(111)$ & $\mathrm{CoO}(111)$ & $\mathrm{Cu}(111)$ & $\mathrm{Cu}_{2} \mathrm{O}(111)$ & $\mathrm{ZrO}_{2}(111)$ \\
\hline $\mathrm{Ni} / \mathrm{Zr}$ oxides & 12.8 & - & - & - & - & 8.4 \\
$\mathrm{Co} / \mathrm{Zr}$ oxides & - & 11.8 & 3.3 & - & - & 10.3 \\
$\mathrm{Cu} / \mathrm{Zr}$ oxides & - & - & - & 23.2 & - & 5.5 \\
$\mathrm{Ni} / \mathrm{Al}$ oxides & 8.1 & - & - & - & - & - \\
$\mathrm{Co} / \mathrm{Al}$ oxides & - & - & - & - & - & - \\
$\mathrm{Cu} / \mathrm{Al}$ oxides & - & - & - & 22.5 & 7.5 & - \\
\hline
\end{tabular}

Table 2 Composition and textural properties of tested catalysts

\begin{tabular}{llllll}
\hline Catalyst & $\begin{array}{l}\text { Main metal } \\
(\text { mass\% })\end{array}$ & $\begin{array}{l}\text { Zirconia/aluminia } \\
(\text { mass\%) }\end{array}$ & $\mathrm{S}_{\mathrm{BET}}\left(\mathrm{m}^{2} / \mathrm{g}\right)$ & $\mathrm{V}_{\mathrm{p}}\left(\mathrm{cm}^{3} / \mathrm{g}\right)$ & $\mathrm{D}_{\mathrm{p}}(\mathrm{nm})$ \\
\hline Co/Zr oxides & 63.8 & 36.2 & 89 & 0.16 & 7 \\
$\mathrm{Cu} / \mathrm{Zr}$ oxides & 63.8 & 36.2 & 23 & 0.07 & 13 \\
$\mathrm{Ni} / \mathrm{Al}$ oxides & 63.8 & 36.2 & 146 & 0.18 & 5 \\
$\mathrm{Co} / \mathrm{Al}$ oxides & 63.8 & 36.2 & 27 & 0.15 & 22 \\
$\mathrm{Cu} / \mathrm{Al}$ oxides & 63.8 & 36.2 & 13 & 0.04 & 13 \\
\hline
\end{tabular}

at $473 \mathrm{~K}$ for $4 \mathrm{~h}$. The catalytic activity in the ethanol conversion was determined under the following conditions: atmospheric pressure, temperature range dependent on catalyst activity within $433-873 \mathrm{~K}$, space velocity of the reactants flow $100 \mathrm{ml} / \mathrm{min}$, initial molar ratio of ethanol to water equal to 1:3 under pure $\mathrm{N}_{2}$ flow. The feed gas was deoxidized with the BTS deoxidizer and dehydrated with the molecular sieve $5 \AA$ A. Substrates and products were directed on-line to chromatograph Varian Star 3800. Then the gases were decompressed to the atmospheric pressure and cooled to separate the liquid fraction. The gaseous products were analyzed in the system of Carbo Plot P7 column, $25 \mathrm{~m}$ $0.53 \mathrm{~mm}$ and Supelcowax 10 column, $30 \mathrm{~m} \cdot 0.32 \mathrm{~mm}$. Ethanol was determined quantitatively in the Supelcowax 10 column and FID detector and the remaining gases in the Carbo Plot P7 column and TCD detector. Additionally carbon monoxide and methane were determined quantitatively in the methanizer with the sensitivity of $20 \mathrm{ppb}$ [31]. Time on stream was between 23 and $36 \mathrm{~h}$.

Activity of tested catalysts was characterized by hydrogen yield, ethanol conversion and selectivities of carbon monoxide and methane according to formulas given below [32]:

$$
W_{\mathrm{H}_{2}}=\frac{V_{\mathrm{H}_{2}}}{m_{\text {cat. }}} \quad\left(\mathrm{L} / \mathrm{kg}_{\text {cat. }} \cdot \mathrm{h}\right)
$$




$$
\begin{gathered}
\alpha=\frac{F_{\mathrm{Et}}^{\mathrm{in}}-F_{\mathrm{Et}}^{\mathrm{out}}}{F_{\mathrm{Et}}^{\mathrm{in}}} 100(\%) \\
S_{\mathrm{i}}=\frac{F_{\mathrm{i}}^{\text {out }}}{2\left(F_{\mathrm{Et}}^{\text {in }}-F_{\mathrm{Et}}^{\text {out }}\right)} 100 \%
\end{gathered}
$$

Here $\mathrm{m}_{\text {cat. }}(\mathrm{g})$ is the catalyst mass, $\mathrm{V}_{\mathrm{H}_{2}}(\mathrm{~L} / \mathrm{h})$ is the volume flow rate, $\mathrm{F}_{\mathrm{i}}^{\mathrm{in}}$ and $\mathrm{F}_{\mathrm{i}}^{\text {out }}$ $(\mathrm{mol} / \mathrm{h})$ is the molar flow rate of $\mathrm{i}$-th component at input $(\mathrm{EtOH})$ and output $(\mathrm{CO}$, $\mathrm{CH}_{4}$ ), respectively.

\section{Results and discussion}

The phase composition of prepared catalysts was determined by XRD investigations presented in Fig. 1. The phase analysis revealed a presence of dominant peaks between $2 \theta=40-44^{\circ}$ connected to $\mathrm{Ni}^{0}, \mathrm{Co}^{0}$ and $\mathrm{Cu}^{0}$. Some of the peaks of weak intensity observed in samples of catalysts containing zirconia were caused by its crystallization (Fig. 1a). Other peaks were connected to $\mathrm{CoO}$. For the $\mathrm{Co} / \mathrm{Al}$ oxides catalyst it was not possible to fit phases (Fig. 1b) because of low intensity of signals, so the description of reflexes missed. Other peaks in Fig. 1b were connected to

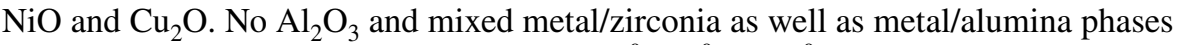
were detected. The crystallite sizes of the $\mathrm{Ni}^{0}, \mathrm{Co}^{0}$ or $\mathrm{Cu}^{0}$ are different. Calculation of crystallite size of $\mathrm{Co} / \mathrm{Al}$ oxides catalyst by Scherrer method (Table 1) was not possible.

Values of specific surface area BET, pore volume and average pore diameter are presented in Table 2. Specific surface area and total pore volume $\left(\mathrm{V}_{\mathrm{p}}\right)$ decreased in following order: $\mathrm{Ni} / \mathrm{Al}>\mathrm{Ni} / \mathrm{Zr}>\mathrm{Co} / \mathrm{Zr}>\mathrm{Co} / \mathrm{Al}>\mathrm{Cu} / \mathrm{Zr}>\mathrm{Cu} / \mathrm{Al}$ oxides. The $\mathrm{Ni} / \mathrm{Zr}$ oxides and $\mathrm{Ni} / \mathrm{Al}$ oxides catalysts revealed the highest values of $\mathrm{S}_{\mathrm{BET}}$ and $\mathrm{V}_{\mathrm{p}}$ over 10 times higher than those of $\mathrm{Cu} / \mathrm{Zr}$ oxides and $\mathrm{Cu} / \mathrm{Al}$ oxides (Table 2). The value of total pore volume of obtained catalysts reached about 0.2 $\mathrm{cm}^{3} / \mathrm{g}$. There was found correlation between specific surface area and value of

(a)

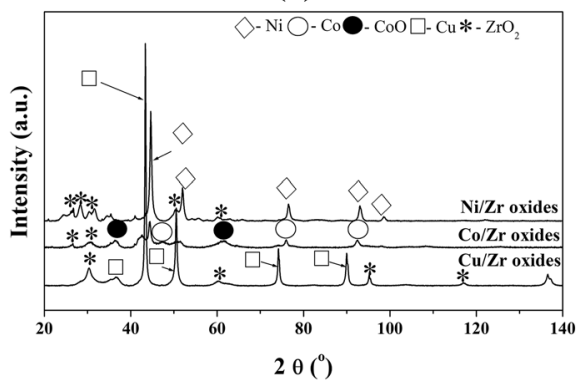

(b)

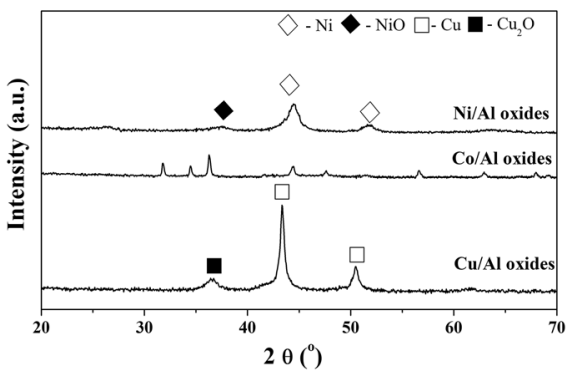

Fig. 1 XRD patterns of tested catalysts 
crystallite size of active metal (see Tables 1,2 ). The $\mathrm{Cu} / \mathrm{Zr}$ oxides and $\mathrm{Cu} / \mathrm{Al}$ oxides catalysts revealed the lowest values of specific surface area $\left(23 \mathrm{~m}^{2} / \mathrm{g}\right.$ and $13 \mathrm{~m}^{2} / \mathrm{g}$ respectively) and the highest values of crystallite sizes of $\mathrm{Cu}^{0}(23.3 \mathrm{~nm}$ and $22.5 \mathrm{~nm}$ respectively).

$\mathrm{H}_{2}$-TPR profiles of investigated catalysts are presented in Fig. 2. Ni/Zr oxides catalyst showed broad peaks: low-temperature one with maximum at $662 \mathrm{~K}$ and high-temperature one with maximum at $799 \mathrm{~K}$. The first one is responsible for reduction of $\mathrm{NiO}$ to $\mathrm{Ni}^{0}$, the second one-for reduction of strongly dispersed $\mathrm{NiO}$ in $\mathrm{Zr}$ oxide [19]; it was not proved by XRD investigations. TPR profile of Ni/Al oxides catalyst revealed a single very broad reduction peak at higher temperature of $820 \mathrm{~K}$ comparing with $\mathrm{Ni} / \mathrm{Zr}$ oxides catalyst. TPR profiles of $\mathrm{Co} / \mathrm{Zr}$ oxides and $\mathrm{Co} / \mathrm{Al}$ oxides catalysts revealed 3 reduction peaks of various intensity, two lowtemperature ones at $627 \mathrm{~K}(\mathrm{Co} / \mathrm{Al}$ oxides $), 631 \mathrm{~K}(\mathrm{Co} / \mathrm{Zr}$ oxides $)$ and $671 \mathrm{~K}(\mathrm{Co} /$ $\mathrm{Al}$ oxides), $682 \mathrm{~K}$ (Co/Zr oxides). High-temperature maximum was observed at $771 \mathrm{~K}$ and $938 \mathrm{~K}$, respectively. The first peaks were connected with two-stage reduction of $\mathrm{Co}_{3} \mathrm{O}_{4}$ to $\mathrm{CoO}$ and to $\mathrm{Co}^{0}$. The last peak was connected with reduction of $\mathrm{CoO}$ strongly connected with $\mathrm{Zr}$ oxide or $\mathrm{Al}$ oxide $[7,20]$. $\mathrm{Co} / \mathrm{Al}$ oxides catalyst was reduced at lower temperatures than $\mathrm{Co} / \mathrm{Zr}$ oxides. $\mathrm{Cu} / \mathrm{Zr}$ oxides catalyst was reduced from $\mathrm{CuO}$ to $\mathrm{Cu}^{0}$, it revealed strong single peak at $582 \mathrm{~K}$ [33]. $\mathrm{Cu} / \mathrm{Al}$ oxides catalyst was reduced at temperature about $30 \mathrm{~K}$ higher than $\mathrm{Cu} / \mathrm{Zr}$ oxides catalyst. A broad peak was observed, which contained reduction of $\mathrm{CuO}$ to $\mathrm{Cu}_{2} \mathrm{O}$ followed by reduction to $\mathrm{Cu}^{0}$; it was proved by XRD investigations. As shown by the $\mathrm{H}_{2}-\mathrm{TPR}$ profile, the $\mathrm{Cu} / \mathrm{Al}$ catalyst is fully reduced to $\mathrm{Cu}^{0}$ at $617 \mathrm{~K}$. On the other hand, on the XRD spectra, there is a relatively intense $\mathrm{Cu}_{2} \mathrm{O}$ reflex, which may indicate its partial oxidation after the reaction (Figs. 1b, 2b).

Catalytic activity results are presented graphically in Figs. 3, 4, 5 and 6 and Table 3.

All catalysts achieved a high degrees of conversion (Fig. 3a, b).

Zirconia containing catalysts (Figs. 3a, 4a, 5a, 6a).

$\mathrm{Ni} / \mathrm{Zr}$ oxides catalyst reaches the highest hydrogen yield of $-756 \mathrm{~L} /\left(\mathrm{kg}_{\text {cat. }} \mathrm{h}\right)$ at $773 \mathrm{~K}$, unfortunately accompanied by high production of carbon monoxide (selectivity 13\%) and methane (selectivity about 32\%).

(a)

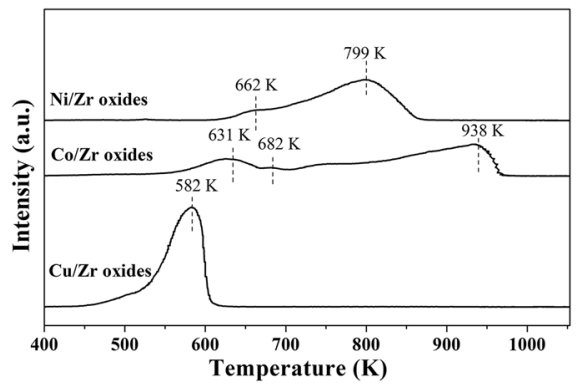

(b)

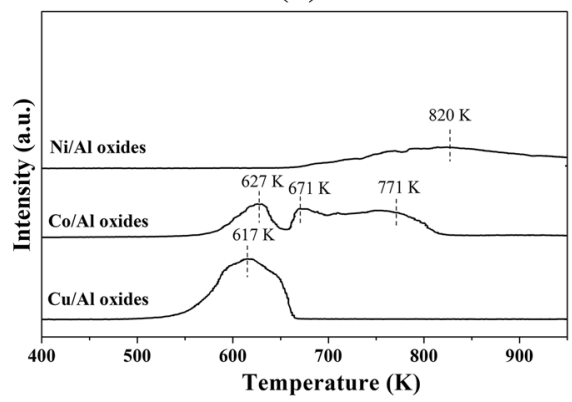

Fig. $2 \mathrm{H}_{2}$-TPR profiles of tested catalysts 
(a)

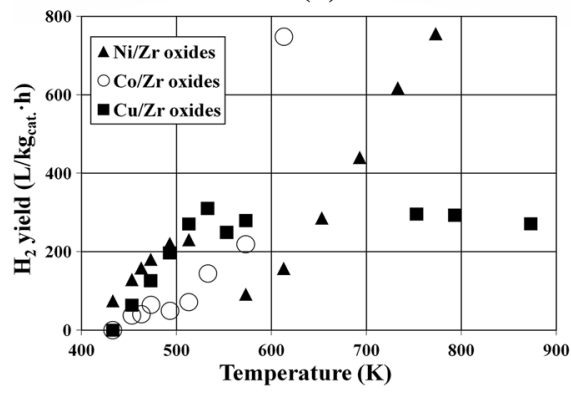

(b)

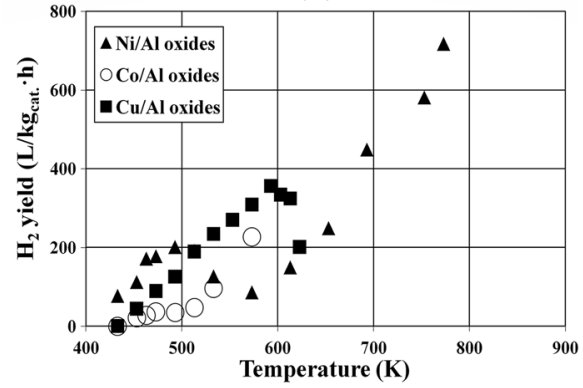

Fig. $3 \mathrm{H}_{2}$ yield as a function of the temperature for a zirconia and $\mathbf{b}$ alumina containing catalysts

(a)

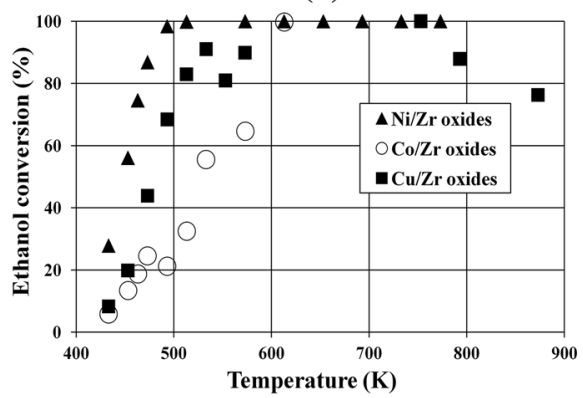

(b)

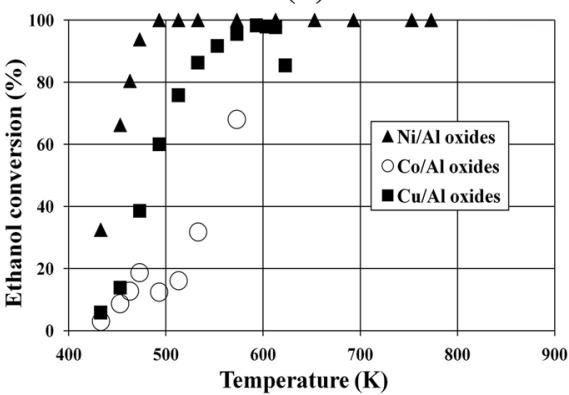

Fig. 4 Ethanol conversion as a function of the temperature for a zirconia and $\mathbf{b}$ alumina containing catalysts

(a)

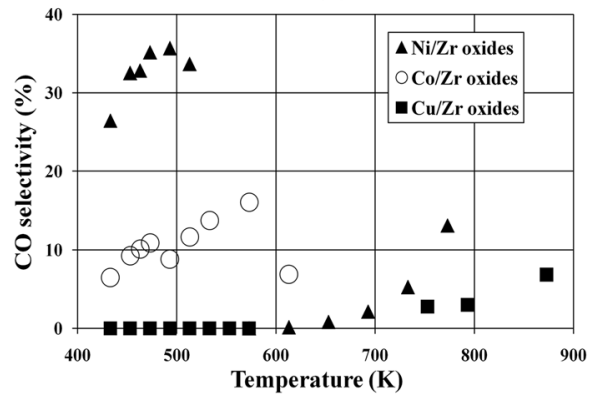

(b)

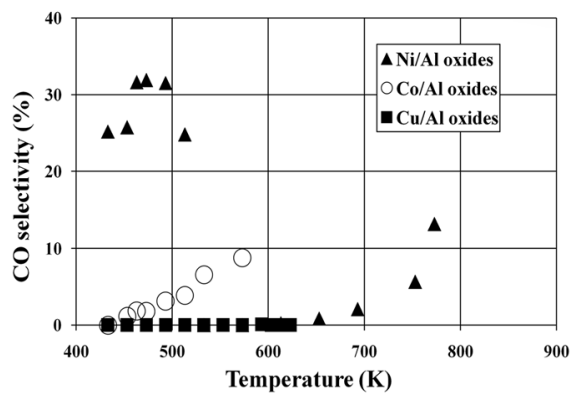

Fig. $5 \mathrm{CO}$ selectivity as a function of temperature for $\mathbf{a}$ zirconia and $\mathbf{b}$ alumina containing catalysts

$\mathrm{Co} / \mathrm{Zr}$ oxides catalyst reaches a little lower hydrogen yield of $748 \mathrm{~L} /\left(\mathrm{kg}_{\text {cat. }}\right.$ h) than $\mathrm{Ni} / \mathrm{Zr}$ oxides catalyst, but at lower temperature of $613 \mathrm{~K}$ (Fig. 3a). In the range of 433-573 $\mathrm{K}$ carbon monoxide and methane selectivities increase with the temperature. Further increase in temperature causes rapid decrease in carbon 
(a)

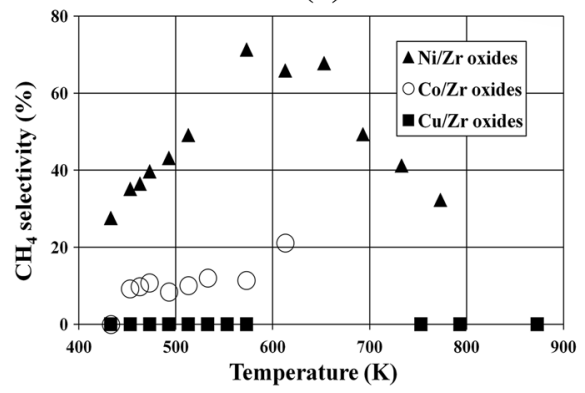

(b)

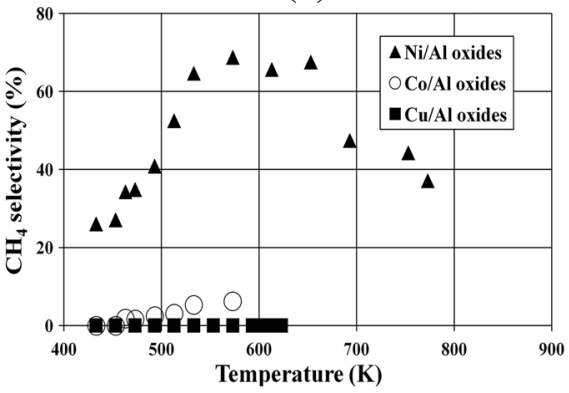

Fig. $6 \mathrm{CH}_{4}$ selectivity as a function of for a zirconia and $\mathbf{b}$ alumina containing catalysts

Table 3 Maximum hydrogen yield at corresponding temperature for tested catalysts

\begin{tabular}{lllrcr}
\hline Catalyst & $\mathrm{T}(\mathrm{K})$ & $\left(\mathrm{L} / \mathrm{kg}_{\text {cat. }} \mathrm{h}\right)$ & $\alpha(\%)$ & $\mathrm{S}_{\mathrm{CO}}(\%)$ & $(\%)$ \\
\hline Ni/Zr oxides & 773 & 756 & 100 & 13 & 32 \\
$\mathrm{Co} / \mathrm{Zr}$ oxides & 613 & 748 & 100 & 7 & 21 \\
$\mathrm{Cu} / \mathrm{Zr}$ oxides & 533 & 309 & 91 & 0 & 0 \\
$\mathrm{Ni} / \mathrm{Al}$ oxides & 773 & 717 & 100 & 13 & 37 \\
$\mathrm{Co} / \mathrm{Al}$ oxides & 573 & 227 & 68 & 9 & 6 \\
$\mathrm{Cu} / \mathrm{Al}$ oxides & 593 & 356 & 98 & 0 & 0 \\
\hline
\end{tabular}

monoxide selectivity to $7 \%$ and increase in methane selectivity to $21 \%$ at $613 \mathrm{~K}$ (Figs. 5a, 6a).

It is worth emphasizing the fact that the $\mathrm{Cu} / \mathrm{Zr}$ oxides catalyst showed very good selectivity. Hydrogen yield in the temperature range 513-873 K remained relatively stable but significantly lower $-271 \mathrm{~L} /\left(\mathrm{kg}_{\text {cat. }}\right.$ h) than over the $\mathrm{Co} / \mathrm{Zr}$ oxides and $\mathrm{Ni} / \mathrm{Zr}$ oxides catalysts at $613 \mathrm{~K}$ and $773 \mathrm{~K}$ respectively (Fig. 3a). In the hydrogen output stream, carbon monoxide appeared above $600 \mathrm{~K}$ and its selectivity did not exceed $3 \%$ in the higher temperature range (Fig. $5 \mathrm{a}$ ). $\mathrm{No} \mathrm{CH}_{4}$ has been detected (Fig. 6a).

Alumina containing catalysts (Figs. 3b, 4b, 5b, 6b).

$\mathrm{Ni} / \mathrm{Al}$ oxides catalyst showed similar to $\mathrm{Ni} / \mathrm{Zr}$ oxides hydrogen yield $\left(717 \mathrm{~L} / \mathrm{kg}_{\text {cat. }}\right.$. h)) and $\mathrm{CO}$ selectivity of $13 \%$ with a $\mathrm{CH}_{4}$ selectivity about $35 \%$ at $773 \mathrm{~K}$ (Table 3 ). Unfortunately, this catalyst has become sintered. Taking into account the hydrogen efficiency, selectivities towards by-products (carbon monoxide and methane) and sintering of the catalyst, hydrogen production should be carried out at temperatures below $753 \mathrm{~K}$ (Figs. 5b, 6b).

$\mathrm{Co} / \mathrm{Al}$ oxides catalyst compared to $\mathrm{Co} / \mathrm{Zr}$ oxides showed a slightly higher hydrogen yield $\left(227 \mathrm{~L} /\left(\mathrm{kg}_{\text {cat }} \cdot \mathrm{h}\right)\right)$ as well as over two times lower CO selectivity $(8 \%)$ and almost twice lower $\mathrm{CH}_{4}$ selectivity (6\%) at $573 \mathrm{~K}$ (Table 3). Similarly to the $\mathrm{Ni} / \mathrm{Al}$ oxides catalyst, it has become deactivated, so the process should be carried out at temperatures below $613 \mathrm{~K}$.

$\mathrm{Cu} / \mathrm{Al}$ oxides catalyst showed a higher hydrogen yield of $\left.309 \mathrm{~L} / \mathrm{kg}_{\text {cat. }} \mathrm{h}\right)$ at $573 \mathrm{~K}$ than $\mathrm{Cu} / \mathrm{Zr}$ oxides (Fig. 3a, b). Above this temperature the yield reached its 
maximum and then rapidly decrease. Similarly to $\mathrm{Cu} / \mathrm{Zr}$ oxides catalyst, neither $\mathrm{CO}$ nor $\mathrm{CH}_{4}$ were found in the products (Figs. 5b, 6b).

Experimental results are collected in Table 3. The tested catalysts achieved their activity toward hydrogen production for different temperature ranges, therefore the table shows the maximum hydrogen efficiencies and corresponding temperatures.

The correlation between activity of examined catalysts and textural properties was not found. The only relationship that has been found is between pore diameter and hydrogen yield: about $50 \%$ increase in pore diameter caused a decrease in hydrogen yield (see Table 2).

There was found, that decrease in crystallite sizes of the $\mathrm{Ni}^{0}, \mathrm{Co}^{0}$ phase gave an improvement of its dispersion followed by high hydrogen yield (Fig. 1, Table 1). $\mathrm{Ni} / \mathrm{Al}$ oxides catalyst had the highest values of specific surface area BET $\left(146 \mathrm{~m}^{2} / \mathrm{g}\right)$ and total pore volume $\left(0.18 \mathrm{~cm}^{3} / \mathrm{g}\right)$ and the lowest values of crystallite sizes of the $\mathrm{Ni}^{0}(8.1 \mathrm{~nm})$. Large crystallites and large pore diameters of $\mathrm{Cu} / \mathrm{Zr}$ oxides and $\mathrm{Cu} / \mathrm{Al}$ oxides catalysts could be responsible for the agglomeration of metal therefore giving low values of specific surface area BET and total pore volume and in effect low values of hydrogen yield (Tables 1, 2, 3).

Based on TPR and test results, the lower hydrogen reduction temperature corresponds to the lower temperature at which the catalysts achieve maximum hydrogen efficiency (Fig. 2, Table 3). In the case of $\mathrm{Cu} / \mathrm{Zr}$ oxides and $\mathrm{Cu} / \mathrm{Al}$ oxides catalysts, the $\mathrm{H}_{2}-\mathrm{TPR}$ peaks at lower reduction temperatures were connected with large crystallites that caused decreased dispersion (Fig. 2, Table 1).

\section{Summary}

This paper presents studies on the activity of $\mathrm{Cu} / \mathrm{Zr}$ oxides and $\mathrm{Cu} / \mathrm{Al}$ oxides catalysts in the ethanol steam reforming process. Their activity was compared with $\mathrm{Ni} /$ $\mathrm{Zr}, \mathrm{Co} / \mathrm{Zr}, \mathrm{Ni} / \mathrm{Al}$ and $\mathrm{Co} / \mathrm{Al}$. The $\mathrm{Ni} / \mathrm{Zr}$ oxides catalyst, characterized by high hydrogen efficiency of $756 \mathrm{~L} /\left(\mathrm{kg}_{\text {cat. }} \mathrm{h}\right)$ at $100 \%$ ethanol conversion at $773 \mathrm{~K}$, appeared to be the best catalyst among the ones investigated by us in the steam reforming process. The copper catalysts $(\mathrm{Cu} / \mathrm{Zr}$ oxides and $\mathrm{Cu} / \mathrm{Al}$ oxides) showed lower hydrogen efficiency $\left(309 \mathrm{~L} /\left(\mathrm{kg}_{\text {cat. }} \mathrm{h}\right)\right.$ at $533 \mathrm{~K}$ and $356 \mathrm{~L} /\left(\mathrm{kg}_{\text {cat. }} \mathrm{h}\right)$ at $593 \mathrm{~K}$, respectively), but their significant advantage is the lack of $\mathrm{CO}$ formation, which is of a great importance in the aspect of using the produced hydrogen in fuel cells.

The correlation between activity of examined catalysts and textural properties was not found. The only relationship that has been found is between pore diameter and hydrogen yield: about $50 \%$ increase in pore diameter caused a decrease in hydrogen yield.

The attempts to apply bicomponent copper-based catalysts $(\mathrm{Cu} / \mathrm{Al}$ oxides and $\mathrm{Cu} /$ $\mathrm{Zr}$ oxides) in the ethanol steam reforming process showed their excellent selectivity and good resistance to coking. However, they revealed unsatisfactory activities due to low hydrogen yields. It seems reasonable to continue investigations to modify the chosen $\mathrm{Cu} / \mathrm{Zr}$ oxides catalyst in order to obtain higher hydrogen efficiency. Some promoters will be tested. 
Open Access This article is licensed under a Creative Commons Attribution 4.0 International License, which permits use, sharing, adaptation, distribution and reproduction in any medium or format, as long as you give appropriate credit to the original author(s) and the source, provide a link to the Creative Commons licence, and indicate if changes were made. The images or other third party material in this article are included in the article's Creative Commons licence, unless indicated otherwise in a credit line to the material. If material is not included in the article's Creative Commons licence and your intended use is not permitted by statutory regulation or exceeds the permitted use, you will need to obtain permission directly from the copyright holder. To view a copy of this licence, visit http://creativecommons.org/licen ses/by/4.0/.

\section{References}

1. Ogo S, Sekine Y (2020) Recent progress in ethanol steam reforming using non-noble transition metal catalysts: a review. Fuel Process Technol 199:106238-106249. https://doi.org/10.1016/j.fupro c. 2019.106238

2. Gonzalez-Gil R, Chamorro-Burgos I, Herrera C, Larrubia MA, Laborde M, Marino F, Alemany LJ (2015) Production of hydrogen by catalytic steam reforming of oxygenated model compounds on Ni-modified supported catalysts. Simulation and experimental study. Int J Hydrogen Energy 40:11217-11227. https://doi.org/10.1016/j.ijhydene.2015.05.167

3. Madej-Lachowska M, Kulawska M, Słoczyński J (2017) Methanol as a high purity hydrogen source for fuel cells: a brief review of catalysts and rate expressions. Chem Proc Eng 38:147-162. https:// doi.org/10.1515/cpe-2017-0012

4. Rashid MM, Al Mesfer MK, Naseem H, Danish M (2015) Hydrogen production by water electrolysis: a review of alkaline water electrolysis, PEM water electrolysis and high temperature water electrolysis. Int J Eng Adv Technol 4:80-93

5. Ni M, Leung DYC, Leung MKH (2007) A review on reforming bio-ethanol for hydrogen production. Int J Hydrogen Energy 32:3238-3247. https://doi.org/10.1016/j.ijhydene.2007.04.038

6. Vizcaino AJ, Carrero A, Calles JA (2007) Hydrogen production by ethanol steam reforming over $\mathrm{Cu}-\mathrm{Ni}$ supported catalysts. Int J Hydrogen Energy 32:1450-1461. https://doi.org/10.1016/j.ijhyd ene.2006.10.024

7. Batista MS, Santos RKS, Assaf EM, Assaf JM, Ticianelli EA (2004) High efficiency steam reforming of ethanol by cobalt-based catalysts. J Power Sources 134:27-32. https://doi.org/10.1016/j.jpows our.2004.01.052

8. Augusto BL, Ribeiro MC, Aires FJCS, da Silva VT, Noronha FB (2018) Hydrogen production by the steam reforming of ethanol over cobalt catalysts supported on different carbon nanostructures. Today Catal. https://doi.org/10.1016/j.cattod.2018.10.029

9. Sharma PK, Saxena N, Roy PK, Bhat A (2016) Hydrogen generation by ethanol steam reforming over $\mathrm{Rh} / \mathrm{Al}_{2} \mathrm{O}_{3}$ and $\mathrm{Rh} / \mathrm{CeZrO}_{2}$ catalysts: a comparative study. Int J Hydrogen Energy 41:61236133. https://doi.org/10.1016/j.ijhydene.2015.09.137

10. Frusteri F, Freni S, Spadaro L, Chiodo V, Bonura G, Donato S, Cavallaro S (2004) $\mathrm{H}_{2}$ production for $\mathrm{MC}$ fuel cell by steam reforming of ethanol over $\mathrm{MgO}$ supported $\mathrm{Pd}, \mathrm{Rh}, \mathrm{Ni}$ and Co catalysts. Catal Commun 5:611-615. https://doi.org/10.1016/j.catcom.2004.07.015

11. Palma V, Castaldo F, Ciambelli P, Iaquaniello G (2014) H2 production for MC fuel cell by steam reforming of ethanol Over $\mathrm{MgO}$ supported $\mathrm{Pd}, \mathrm{Rh}, \mathrm{Ni}$ and Co catalysts. Appl Catal B Environ 145:73-84. https://doi.org/10.1016/j.apcatb.2013.01.053

12. Jia H, Zhang J, Yu J, Yang X, Sheng X, Xu H, Sun Ch, Shen W, Goldbach A (2019) Efficient $\mathrm{H}_{2}$ production via membrane-assisted ethanol steam reforming over $\mathrm{Ir} / \mathrm{CeO}_{2}$ catalyst Int. J Hydrogen Energy 44:24733-32475. https://doi.org/10.1016/j.ijhydene.2019.07.199

13. Fajardo HV, Longo E, Mezalira D, Nuernberg G, Almerindo G, Collasiol A, Probst LFD, Garcia ITS, Carreño NLV (2010) Influence of support on catalytic behavior of nickel catalysts in the steam reforming of ethanol for hydrogen production. Environ Chem Lett 8:79-85. https://doi.org/10.1007/ s10311-008-0195-5

14. Araiza DG, Gómez-Cortés A, Díaz G (2018) Effect of ceria morphology on the carbon deposition during steam reforming of ethanol over $\mathrm{Ni} / \mathrm{CeO}_{2}$ catalysts. Catal Today. https://doi.org/10.1016/j. cattod.2018.03.016 
15. Fatsikostas AN, Kondarides DI, Verykios XE (2002) Production of hydrogen for fuel cells by reformation of biomass-derived ethanol. Catal Today 75:145-155. https://doi.org/10.1016/S0920 $-5861(02) 00057-3$

16. Rossetti I, Lasso J, Finocchio E, Ramis G, Nichele V, Signoretto M, Di Michele A (2014) $\mathrm{TiO}_{2}$-supported catalysts for the steam reforming of ethanol. Appl Catal A Gen 477:42-53. https:// doi.org/10.1016/j.apcata.2014.03.004

17. Yang Y, Ma J, Wu F (2006) Production of hydrogen by steam reforming of ethanol over a Ni/ZnO catalyst. Int J Hydrogen Energy 31:877-882. https://doi.org/10.1016/j.ijhydene.2005.06.029

18. Pinton N, Vidal MV, Signoretto M, Martínez-Arias A, Cortés Corberán V (2017) Ethanol steam reforming on nanostructured catalysts of $\mathrm{Ni}, \mathrm{Co}$ and $\mathrm{CeO}_{2}$ : influence of synthesis method on activity, deactivation and regenerability. Catal Today 296:135-143. https://doi.org/10.1016/j.catto d.2017.06.022

19. Li S, Li M, Zhang Ch, Wang S, Ma X, Gong J (2012) Steam reforming of ethanol over $\mathrm{Ni} / \mathrm{ZrO}_{2}$ catalysts: effect of support on product distribution. Int J Hydrogen Energy 37:2940-2949. https:// doi.org/10.1016/j.ijhydene.2011.01.009

20. Padilla R, Benito M, Rodriguez L, Serrano A, Munoz G, Daza L (2010) Nickel and cobalt as active phase on supported zirconia catalysts for bio-ethanol reforming: influence of the reaction mechanism on catalysts performance. Int J Hydrogen Energy 35:8921-8928. https://doi.org/10.1016/j. ijhydene.2010.06.021

21. Bergamaschi VS, Carvalho FMS, Rodrigues C, Fernandes DB (2005) Preparation and evaluation of zirconia microspheres as inorganic exchanger in adsorption of copper and nickel ions and as catalyst in hydrogen production from bioethanol. Chem Eng J 112:153-158. https://doi.org/10.1016/j. cej.2005.04.016

22. Sharma YC, Kumar A, Prasad R, Upadhyay SN (2017) Ethanol steam reforming for hydrogen production: latest and effective catalyst modification strategies to minimize carbonaceous deactivation. Renew Sustain Energy Rev 74:89-103. https://doi.org/10.1016/j.rser.2017.02.049

23. Llorca J, Homs N, Sales J, de la Piscina PR (2002) Efficient production of hydrogen over supported cobalt catalysts from ethanol steam reforming. J Catal 209:306-317. https://doi.org/10.1006/ jcat.2002.3643

24. Haga F, Nakajima T, Miya H, Mishima S (1997) Catalytic properties of supported cobalt catalysts for steam reforming of ethanol. Catal Lett 48:223-227. https://doi.org/10.1023/A:1019039407126

25. Cavallaro S, Mondello N, Freni S (2001) Hydrogen produced from ethanol for internal reforming molten carbonate fuel cell. J Power Sources 102:198-204. https://doi.org/10.1016/S0378 -7753(01)00800-X

26. Greluk M, Rotko M, Słowik G, Turczyniak-Surdacka S (2019) Hydrogen production by steam reforming of ethanol over $\mathrm{Co} / \mathrm{CeO} 2$ catalysts: effect of cobalt content. J Energy Inst 92:222-238. https://doi.org/10.1016/j.joei.2018.01.013

27. Llorca J, Homs N, Sales J, Fierro JLG, de la Piscina PR (2004) Effect of sodium addition on the performance of Co-ZnO-based catalysts for hydrogen production from bioethanol. J Catal 222:470480. https://doi.org/10.1016/j.jcat.2003.12.008

28. Song H, Zhang L, Watson RB, Braden D, Ozkan US (2007) Investigation of bio-ethanol steam reforming over cobalt-based catalysts. Catal Today 129:346-354. https://doi.org/10.1016/j.catto d.2006.11.028

29. Courty Ph, Ajot H, Marcilly Ch, Delmon B (1973) Oxydes mixtes ou en solution solide sous forme très divisée obtenus par décomposition thermique de précurseurs amorphes. Powder Technol 7:2138. https://doi.org/10.1016/0032-5910(73)80005-1

30. Kulawska M, Skrzypek J (2001) Kinetics of the synthesis of higher aliphatic alcohols from syngas over a modified methanol synthesis catalyst. Chem Eng Proc 40:33-40. https://doi.org/10.1016/ S0255-2701(00)00107-0

31. Lachowska M (2010) Steam reforming of methanol over $\mathrm{Cu} / \mathrm{Zn} / \mathrm{Zr} / \mathrm{Ga}$ catalyst: effect of the reduction conditions on the catalytic performance. Reac Kinet Mech Cat 101:85-91. https://doi. org/10.1007/s11144-010-0213-z

32. Szarawara J, Skrzypek J, Gawdzik A (1991) Podstawy inżynierii reaktorów chemicznych, 2nd edn. WNT, Warsaw

33. Kornas A, Grabowski R, Śliwa SK, Ruggiero-Mikołajczyk M, Żelazny A (2017) Dimethyl ether synthesis from $\mathrm{CO}_{2}$ hydrogenation over hybrid catalysts: effects of preparation methods. Reac Kinet Mech Cat 121:317-327 
Publisher's Note Springer Nature remains neutral with regard to jurisdictional claims in published maps and institutional affiliations. 